\title{
Forest land cover continues to exacerbate freshwater acidification despite decline in
} sulphate emissions.

\author{
Dunford, R.W. ${ }^{\mathrm{ab}} *$, Donoghue, D.N.M ${ }^{\mathrm{ac}}$ and Burt, T.P. ${ }^{\mathrm{ad}}$
}

${ }^{a}$ Department of Geography, Durham University, Science Laboratories, South Road, Durham, DH1 4ET

${ }^{b}$ Present address: ECI, Oxford University Centre for the Environment, South Parks Road, Oxford, OX13QY

cdanny.donoghue@durham.ac.uk

d.p.burt@durham.ac.uk

*Corresponding Author. Robert.Dunford@ ouce.ox.ac.uk tel: (+44)1865285183 fax: (+44)1865275850

\section{Abstract}

Evidence from a multi-date regional-scale analysis of both high-flow and annual-average water quality data from Galloway, south-west Scotland, demonstrates that forest land cover continues to exacerbate freshwater acidification. This is in spite of significant reductions in airborne pollutants. The relationship between freshwater sulphate and forest cover has decreased from 1996 to 2006 indicating a decrease in pollutant scavenging. The relationship between forest cover and freshwater acidity $(\mathrm{pH})$ is, however, still present over the same period, and does not show conclusive signs of having declined. Furthermore, evidence for forest cover contributing to a chlorine bias in marine ion capture suggests that forest scavenging of sea-salts may mean that the forest acidification effect may continue in the absence of anthropogenic pollutant inputs, particularly in coastal areas.

Keywords: Freshwater acidification; Forestry; Diffuse pollution; Regional scale analysis; long-term analysis; Remote Sensing; Galloway; Great Britain; Scavenging; Scotland

\section{Capsule}

Relationships between forest land cover and freshwater $\mathrm{pH}$ continue to be evident despite declines in anthropogenic pollutant sulphate deposition; sea-salt scavenging may play a role.

\section{Introduction}

Diffuse pollution poses a major challenge for environmental management. In the context of the forest environment, the forest acidification effect has long linked forest land cover with increased stream acidity and deleterious impacts on freshwater ecology. This is particularly pertinent when large scale afforestation takes place in acid sensitive areas, as changes of land use to forestry can tip the balance towards acidic freshwaters. The introduction of the Water Framework Directive (WFD; 2000/60/EC) and similar legislation (e.g. US Clean Water Act, 1997) requires diffuse pollution to be managed in a way that promotes good ecological status. However, to effectively manage environmental pollution it is important to have a clear understanding of the form that pollution takes and the mechanisms that drive it. 
40 Freshwater acidification occurs when the buffering capacity of a water body is exceeded by 41 acid inputs external to the system. Historically, long-term acidification has resulted where anthropogenic, atmospheric sulphur and nitrogen compounds have tipped the acid-base balance of freshwater systems (Henriksen, 1980). In addition, episodic acidification also occurs in response to individual natural events particularly during high-discharge or sea-salt events, or following droughts (Hindar et al., 2004; Laudon, 2008; Erlandsson, 2010). The role of the forest land use in acidification, the "forest acidification effect", is in addition to these mechanisms. Early paired catchment studies showed that sites under forest land cover were more acid than moorland sites on similar geologies with similar deposition conditions (Harriman and Morrison, 1982; Stoner et al., 1984). The primary mechanism to which this forest acidification effect has been attributed is the enhanced filtration of airborne sulphur and nitrogen compounds as a result of the increased surface roughness of forest canopies: the forest scavenging effect of Fowler et al. (1989).

Since 1990, however, levels of atmospheric pollutants have reduced significantly as a result of international protocols (e.g. CLRTAP, 1979; Gothenburg Protocol, 1999). In the UK, this has corresponded to a reduction in output of both airborne sulphur (91\%) and nitrogen ( 50\%) (ROTAP draft, 2010). These reductions have led many authors suggest that the impact of forestry on acid waters will decline (Nisbet et al., 1995; Neal et al., 2004; Gagkas et al., 2007). Conversely, studies looking at the long-term recovery of forest ecosystems have continued to raise the issue of an ongoing impact of forests on freshwaters (Helliwell et al., 2001; Harriman et al., 2003; Langan and Hirst, 2004; Neal et al., 2010; Feeley et al., 2010) and despite evidence for recovery at many UK acid waters monitoring sites, three of the five sites with forested catchments show no evidence of recovery and one shows ongoing deterioration (Davies et al., 2005). Part of the difficulty in assessing the impact of forests on acidification is the lack of datasets designed specifically to address diffuse pollution. Paired catchment approaches (Langan and Hirst, 2004; Ormerod and Durance, 2009; Neal et al., 2010) are site specific and do not address the regional scale at which the pollution operates. However, regional studies are difficult to implement and are, as a result, rare (Wright and Henriksen, 1980; Harriman et al., 1987; Ormerod et al., 1989, Buffam et al., 2007; Ågren et al., 2010). This is particularly true for regional surveys that deliberately target individual high-flow events where forest impacts on episodic acidification are expected to be the greatest (Puhr et al. 2000) and none have addressed long-term changes in the forest acidification effect in this manner. 
This paper aims to address this gap in knowledge directly by quantifying differences in freshwater quality between land uses at the scale of Galloway forest district. Eight regionalscale water quality datasets are collected from 1989 to 2006, three of which specifically target high-flow conditions. These data are then analysed using both simple linear and multiple regression analyses to answer the following questions:

a) Are there significant differences between water quality between forest and moorland sites under conditions of decreased deposition?

b) To what extent is sulphate deposition still the driving mechanism behind the forest acidification effect?

c) What are the implications of these findings for the management of diffuse pollution risks?

\section{Study Area and Regional Context}

The study focuses on the seven major catchments of Galloway Forest District in South West Scotland (Figure 1). Galloway Forest District has played an important role in the international research into freshwater acidification and the forest acidification effect since the early years of the acid rain debate (Wright and Henriksen, 1980; Harriman and Morrison, 1982; Battarbee (1984); Helliwell et al., 2001; Puhr et al., 2000; Langan and Hirst, 2004). Afforestation began in the 1940s but peaked 1960-1980; it is now the largest productive forest in the UK boasting 97,000 ha of production forest within a considerably wider forest park. The majority of plantations are still Sitka spruce monocultures (Picea sitchensis) or mixtures with lodgepole pine (Pinus contorta). Soils are generally thin, and consist primarily of podzols and peaty podzols; a large proportion of the uplands are covered by blanket peat (Bown et al., 1982). Non-forest areas are generally peat moorland, with some small patches of rough and improved grassland in the Galloway lowlands.

The Galloway region receives relatively small inputs of sulphate $\left(<21 \mu \mathrm{eql}^{-1} \mathrm{SO}_{4}\right.$ in rainfall 1997, Figure 2A-B). Nonetheless, the poor buffering capacity of the region's geology makes the area naturally acid sensitive. The most acid-sensitive local lithologies are igneous extrusions of tertiary granite; Ordovician shales, mudstones and greywackes are also shown to be acid-sensitive but local Silurian rocks (also shales, mudstones and greywacke) are relatively well buffered (Puhr et al., 2000; Figure 2C).

Regional pollutant sulphate deposition is greatest in the upland regions of the Cree, Dee and Fleet catchments and decreases towards the coast (Figure 2D-F). All forest cover enhances the "dry deposition" of pollutant directly from the atmosphere, however, this transfer is significantly greater where it is exposed to cloud moisture (Fowler et al., 1989) an effect more 
111 common at altitudes over 300m (Forestry commission, 2009). Nevertheless, the impacts of

112 acidification have been widespread and severe across Galloway, with many rivers losing a

113 significant proportion of their salmon and trout populations even in areas with very small

114 proportions of their catchments over $300 \mathrm{~m}$, and distant from the main centre of the pollutant

115 deposition (Galloway Fisheries Trust, 1989). This emphasises the disparity between the

116 upland areas where sulphate scavenging would be expected to play the greatest role in

117 enhancing acidification and the areas where the ecological impacts are most severe.

\section{Materials and Methods}

119 This paper takes a regression-based approach to determine the relationships between land use 120 and water quality variables (Ormerod et al. 1989; Kelly-Quinn et al., 1996; Puhr et al., 2000;

121 Buffam et al., 2007; Ågren et al., 2010). Linear regression is used to investigate the 122 relationships between forestry and individual variables; stepwise multiple regression is used 123 to determine the relative influence of forestry amongst other catchment variables. The 124 approach uses eight regional-scale water quality datasets, three collected under high-flow 125 conditions during individual storm events and five drawn from annual averages of records 126 from long-term Scottish Environmental Protection Agency (SEPA) monitoring sites.

127 Water chemistry data

128 This paper uses a reanalysis of the data of Puhr et al. (2000) as an indication of water quality 129 status in Galloway under conditions of higher deposition; the data were collected on $12^{\text {th }}$ 130 March 1996 for 93 sites during a single storm event. High-flow events were targeted as they 131 commonly promote acid episodes (Welsh and Burns, 1987; Puhr et al., 2000; Laudon et al. 132 1999; Erlandsson et al., 2010). Catchments were selected to represent a range of catchment 133 afforestation (0-100\%) and to be as uniform as possible in terms of geology. Two additional 134 datasets were collected during storm events on $16^{\text {th }}$ March 2005 and $8^{\text {th }}$ March 2006. The 135 surveys used the methodology and sites of Puhr et al. (2000) with 17 additional sites, a total 136 of 110. In terms of hydrology, the 1996 and 2005 surveys caught the peak of the storm; in 1372006 the falling limb was sampled (Figure 3); both the 2005 and 2006 surveys had lower 138 discharges than the 1996 event. In addition, the 1996 and 2005 events have lower mean pH $139\left(\mathrm{pH}_{\mu} \approx 4.7\right)$ than the 2006 event $\left(\mathrm{pH}_{\mu}=5.5\right)$ (Table 1). Furthermore, the 2005 survey shows 140 significant chlorine bias to marine ions ( $\mathrm{Na}: \mathrm{Cl}=0.79)$, suggestive of significant sea-salt inputs. 141 Long-term monitoring data from forty-two SEPA monitoring sites were identified and $\mathrm{pH}$ 142 data were extracted for analysis. Annual median values were calculated for sites where four or 143 more values were available per year. 
Laboratory analysis for the 2005/6 high-flow data used a Dionex DX500 with an EG50 eluent generator with an LC25 chromatography oven to maintain temperature. $2 \mathrm{~mm}$ AS17 and AG17 columns were used for and both anions and cations analysis. A YSI 556 multiparameter probe designed for low-ionic strength waters was used to measure $\mathrm{pH}$. The longterm SEPA water quality data used AQUA 800 colorimetric methods for anion analysis and a Varian Vista Pro ICP-OES spectrometer for cations; pH was measured by titration. Both Durham and SEPA labs applied standard methods for Alkalinity and DOC.

The following 13 water quality variables were compiled:

- $\mathrm{pH}$;

- major anions: sulphate $\left(\mathrm{SO}_{4}{ }^{2-}\right)$, chloride $\left(\mathrm{Cl}^{-}\right)$and nitrate as nitrogen $\left(\mathrm{NO}_{3}-\mathrm{N}\right)$;

- major cations: sodium $\left(\mathrm{Na}^{+}\right)$, calcium $\left(\mathrm{Ca}^{2+}\right)$, magnesium $\left(\mathrm{Mg}^{2+}\right)$ and potassium $\left(\mathrm{K}^{+}\right)$;

- alkalinity (alk) and

- dissolved organic carbon (DOC).

- sodium:Chloride ratio $(\mathrm{Na}: \mathrm{Cl})$,

- charge balance ANC (ANCcb: major cations - major anions / major cations + major anions)

- Forest and Water Guidelines Critical Load Exceedance (CLX: following Gagkas, 2007; Nilsson and Grenfelt 1988 using Critical ANC = 0; with 1995 total catchment sulphur deposition)

\section{Forest Cover Data}

The height of UK upland forestry plantations can be successfully estimated using optical satellite imagery when matched to contemporary field data (Puhr and Donoghue, 2000; Donoghue et al., 2004; Donoghue and Watt, 2006). The approach of Dunford and Donoghue (2007) was taken whereby a single image:field dataset pair is used to classify a series of radiometrically corrected images. LiDAR forest height data from 2003 was used to generate a model with the shortwave infra-red (SWIR) band of a 2003 spot image $\left(R^{2}=0.88\right.$, RMSE 1.53m). Five optical satellite images for the years 1989, 1995, 2001, 2003 and 2005 were radiometrically corrected to one another and the SWIR-based height model was applied to each to generate maps of total forest cover for each of the five years; forest was then defined as trees over $2 \mathrm{~m}$ in height.

\section{Catchment-Based Datasets}

Catchment areas were automatically generated for all water survey points using the Ordnance Survey (OS) Panorama 50m Digital Elevation Model (DEM) (OS, 2004) and ArcGIS (ESRI, CA, USA) hydrology tools. These were each verified against OS map data and then used to extract total forest cover for each catchment. Additional datasets were then extracted at the 
181 catchment scale including: Centre for Ecology and Hydrology (CEH) total sulphur deposition;

182 proportions of igneous, Ordovician and Silurian geology (from British Geological Survey

183 (BGS) 1:65,000 digital maps); mean rainfall 1980-2000 (extrapolated from 104 British

184 Atmospheric Data Centre (BADC) sites) and altitude data (mean catchment altitude from the

185 OS Panorama 50m DEM) (Dunford, 2008). The result was a dataset of water quality data

186 linked to catchment variables within the study area. As only five years of forest data were

187 available, only the long-term data for the years 1989, 1995, 2001, 2003 and 2005 were used.

188 For the high-flow data the forest cover from 1995 was used with the 1996 data; forest cover

189 for 2005 was linked to water quality variables of both the 2005 and 2006 surveys. Each water

190 quality site was then classed by its major geology proportion. All high-flow sites had $>75 \%$

191 uniform geology. Long-term sites had far greater geological variability and sites with <50\%

192 uniform geology were excluded from simple linear regression analysis; this left only the

193 Ordovician geology with sufficient sites for analysis (15-28 sites dependent on the year).

194 However, as many of the 42 sites that had sufficient annual data (>4 records) were included in

195 the multiple regression.

196 Regression Analysis

197 For simple linear regression, each geology subset of the eight water chemistry datasets was

198 regressed separately against forest cover (Table 2; Figure 4). The multiple regression 199 approach tried to identify a statistically significant model with total forest cover, total S 200 deposition, rainfall, maximum altitude and the proportion of igneous and Ordovician geology 201 as the predictor variables. A PCA of these variables identifies the main sources of variation 202 within the dataset (Figure 5). The first principal component (PCA1) correlates with increasing 203 altitude, rainfall, sulphate deposition and igneous rock proportion and with decreasing 204 Ordovician rock proportion. The total forest cover variable has very little correlation with 205 PCA1 suggesting it is independent of the main pattern of dataset variation. For multiple 206 regression, a reflexive, stepwise approach was used and variables were added to the 207 regression model in order of the contribution they play to the overall explanation of the 208 variance within data $\left(R^{2}\right)$ using $\mathrm{P}<0.001, \mathrm{P}<0.01$, and $\mathrm{P}<0.05$ as significance limits. The final 209 model is the model with the greatest statistical significance (lowest $P$ value) in which Total 210 Forestry played a statistically significant contribution (Table 3). If no model significant at $211 \mathrm{P}<0.05$ was identified using an additive approach, all variables were included in the model 212 and removed until all model variables played a statistically significant role. 


\section{Land use differences in a low-deposition climate}

215 Regional-scale freshwater acidity continues to differ between areas of forest and non-forest

216 land cover in Galloway: linear regression identifies statistically significant relationships

217 between forest cover and i) acidic water chemistry in the high-flow surveys 2005/2006 (Table

218 2) and ii) long-term $\mathrm{pH}$ in SEPA datasets for 2003 and 2005 (Figure 4). The differences are

219 identified as positive relationships between forest cover and sulphate, chloride and sodium

220 concentrations and negative relationships with $\mathrm{pH}$, sodium:chloride ratio and charge balance

221 ANC. Multiple regression analyses add support to this (Table 3): total forestry contributes to

222 models significant at $\mathrm{P}<0.001$ for $\mathrm{pH}$ in the 2005 and 2006 single-event and 2003 and 2005

223 long-term surveys. In addition, total forestry contributes to statistically significant models for

224 chlorine, sulphate, charge balance ANC in at least one of the single-event surveys. These

225 relationships are the same as those identified between forest cover and water chemistry in the

226 1980s and 1990s under high-deposition conditions (Harriman and Morrison, 1981; Harriman

227 and Morrison, 1982; Stoner and Gee, 1985; Ormerod and Edwards, 1985, Kreiser et al.,

228 1990). Moreover, the magnitude of the impacts on $\mathrm{pH}$, reductions of between -0.76 and -1.11

$229 \mathrm{pH}$ units (both geologies), fits well with the results of Ormerod et al. (1989) of an effect

230 between -0.6 and -1.0 units. Furthermore, the findings offer regional-scale support to the

231 interpretation of long-term, single-site studies that have suggested that chemical and

232 biological recovery from acidification may be slower in afforested areas than non-forest ones

233 (Langan and Hirst, 2004; Davies et al., 2005; Ormerod and Durance, 2009).

235 Although forest cover has a statistically-significant effect on $\mathrm{pH}$, there are a number of other

236 factors to consider when interpreting the results. Firstly, multiple regression identifies

237 geology as the primary driver of Galloway's pH contributing $>35 \%$ of the explanation of the

238 dataset in both 1996 and 2005 whilst total forest explains 12 and 6\% respectively. The

239 Silurian geology appears well buffered with no evidence of relationships with $\mathrm{pH}$, sulphate,

240 marine ions or DOC seen elsewhere. Secondly, differences in the nature of the individual

241 episodes are quite notable: Ordovician sites, which show clear $\mathrm{pH}$ trends in 2005, show no

242 statistically significant model for $\mathrm{pH}$ during the 2006 event. Furthermore, in 2005 stronger

243 relationships are found with marine ions, as is a statistically significant relationship with DOC

244 that is absent in 1996 and 2006 (Table 2). A number of factors will contribute to these

245 differences, including: impacts of climate change on weather systems (Wright et al., 2006;

246 Wright, 2008); impacts of the North Atlantic Oscillation (NAO) on nitrate and sea salt

247 (Monteith and Evans, 2000; Hindar et al., 2004; Laudon, 2008) as well as the nature of the

248 acid episode (Laudon, 2008; Kroglund et al., 2008; Erlandsson et al., 2010). Finally, 
significant scatter remains even following stratification for geology. With the exception of

250 marine ions on igneous sites in $2005, \mathrm{R}^{2}$ values are consistently $<0.5$. This is to be expected;

251 interconnected soil, river and rainfall factors will also contribute at the local scale to a site's

252 acidity. This does not diminish the importance of the land use differences as the identified

253 relationships are significant at $\mathrm{P}<0.05$. The forest acidification effect exacerbates existing

254 conditions, with the potential to reduce annual-average $\mathrm{pH}$ by -1.19 to -1.81 units and high-

255 flow $\mathrm{pH}$ by -0.71 to -1.11 units depending on initial conditions and geology. In addition, the

256 potential to shift local water chemistry over critical thresholds is demonstrated. For igneous

257 sites in 2005, the $\mathrm{ANC}_{\mathrm{CB}}$ trend (coefficient -0.13 from a y-intercept of 0.05 ) could change the

258 local system from cation to anion dominant. Similarly, at igneous sites in 2006, a forest-

259 related change in the $\mathrm{Na}: \mathrm{Cl}$ ratio (-0.13 from a y-intercept of 1.09) shows the potential to

260 change the system from sodium to chloride dominant.

261

262 A decline in the land use effect?

263 The proportion of the $\mathrm{pH}$ dataset explained by forest cover in the single-date samples has

264 reduced between 1996 and 2005/6 for both igneous $\left(1996 R^{2}=0.36,2005 R^{2}=0.21\right)$ and

265 Ordovician sites $\left(1996 \mathrm{R}^{2}=0.19,2005 \mathrm{R}^{2}=0.08\right)$. This may be evidence for a decline in the

266 forest acidification effect, as may the absence of a statistically significant relationship

267 between $\mathrm{pH}$ and forestry on Ordovician rocks in 2006. Similar declining $\mathrm{R}^{2}$ values are seen in

268 all variables with the exception of marine ions on igneous sites between 1996 and the more

269 recent surveys. Furthermore, the proportion of the variation within the $\mathrm{pH}$ dataset explained

270 by forestry in multiple regression analyses has decreased from 12\% in 1996 to $6 \%$ in 2005.

271

272 In contrast, the $\mathrm{pH}$ records from SEPA's long-term surveys show less evidence for a decrease

273 in the forest acidification (Figure 4). With the exception of 2001 where the relationship was

274 not significant at $\mathrm{P}<0.05$, the relationships between forestry and $\mathrm{pH}$ remain relatively

275 consistent: they have similar form, $\mathrm{R}^{2}$ values in the range $0.25 \leq \mathrm{R}^{2} \leq 0.39$ and the

276 relationship in 2005 has the highest $\mathrm{R}^{2}$ of all. Multiple regression analysis of the SEPA data

277 further supports this. Total Forestry is a key explanatory variable for $\mathrm{pH}$ in both 2003 and

278 2005. It is, therefore, difficult to determine the extent to which the decreased $\mathrm{R}^{2}$ values seen in

279 the high-flow events reflect their individual chemistry or whether the forest acidification

280 effect on overall acidity is in decline.

\section{Mechanisms driving land use differences in acidity}

283 Having identified a significant land use impact on acidity in Galloway it is now necessary to

284 re-evaluate the extent to which sulphate scavenging remains the major mechanism driving the

285 identified trends towards lower $\mathrm{pH}$ in forest areas. Many authors have shown that, even in the 
286 absence of sulphate deposition, natural episodic acidification still take place (Kelly-Quinn $e t$

287 al., 1996; Eshleman et al., 2010; Laudon and Norton, 2010). In fact, Laudon and Bishop 288 (1999) estimate that $80 \%$ of acid episodes are driven by "natural" factors rather than 289 anthropogenic deposition. Erlandsson et al. (2010) studied 258 acid events from 87 Swedish 290 streams (1998-2007) and identified base cation dilution as the major driver for $58 \%$ of the 291 episodes studied, followed by increasing sulphate (26\%), sea-salt deposition (6\%), organic 292 acid (6\%) and nitrate (3\%). Kline et al. (2007) supports this by demonstrating a shift from 293 events driven by increasing inputs of acid anions, to events driven by a dilution of base 294 cations.

296 We now examine the role of land use as a factor with the potential to moderate these drivers 297 either by encouraging additional transfers of sulphate, nitrate, marine or organic anions or by 298 decreasing a water's ability to mitigate acid transfers that occur due to base cation uptake or 299 flow path modification.

\section{Sulphate}

302 Positive relationships between forest cover and sulphate are identified in all single-date 303 surveys at both igneous and Ordovician sites. These match earlier experimental studies 304 performed within the Galloway region (Harriman and Morrison, 1982; Puhr et al., 2000; 305 Harriman et al., 2003). The continued existence of these trends, found 10 years after the last 306 regional survey, indicate that sulphate transfer to freshwaters is still greater in afforested 307 areas. However, the relationship shows signs of having decreased in strength ( $c=15.62 * * *$ in 3081996 but $\mathrm{c}=5.01^{* *}$ and $9.07^{* * *}$ in 2005 and 2006 respectively (Ordovician rocks, Table 2). 309 Nonetheless, although the y-intercept is $10 \mu \mathrm{eql}^{-1}$ lower in 2006 than 1996 and the coefficient 310 in 2006 is half that in 1996, forest cover continues to encourage additional sulphate ions: the 311 coefficient remains positive and significant at $\mathrm{P}<0.01$ in both 2005 and 2006. The likely 312 mechanism for the identified decline is the reduction in sulphate scavenging (Mayer and 313 Ulrich, 1974; Fowler, 1989). With 91\% less sulphate available (ROTAP draft, 2010) the

314 difference in the magnitude of capture between land uses would be expected to decrease.

316 Although scavenging of anthropogenic sulphate has long been considered the major driver of 317 additional sulphate in forest waters it is not the only mechanism by which land use may 318 influence sulphate transfer to freshwaters. Forests also scavenge marine sulphate. The 319 multiple regression analysis shows a negative relationship between the spatial pattern of 320 sulphate deposition and freshwater sulphate concentration even under the high deposition 321 conditions of 1996. The inverse of this trend reflects a South-Western trend towards coastal 
areas and may support the thesis of marine-sourced ion capture: an investigation of rainwater chemistry would resolve help to determine the origins of these ions.

Furthermore, many studies have identified acid episodes as a result of sulphate flushes following droughts (Dillon et al., 1997; Laudon et al., 2004; Laudon and Norton, 2010). Forest drainage and water-uptake by trees can contribute to increased soil drying, particularly immediately following land-use change; additionally, forest floors re-oxidise sulphates which can then be flushed into freshwater systems (Eimers and Dillon, 2002; Eimers et al., 2004). Increased interception and evapotranspiration in forests may also worsen this, particularly in already dry areas (Maitland et al., 1990). However, particularly following droughts, peat bogs are recognised export more sulphate than forests (Eimers et al., 2004). If this were the main mechanism, forest cover would be unlikely to show a positive relationship with sulphate in Galloway. On the other hand, there is potential that catchments with large proportions of waterlogged peat are likely to immobilise sulphate inputs as a result of the prevalence of reducing conditions. A moorland land use effect may result where it is the removal of moorland, rather than the planting of trees, that explains the impacts of afforestation on freshwater sulphate. The Galloway study area includes peat moorlands, mostly in high altitude regions $>600 \mathrm{~m}$ and the Ordovician Luce, Bladnoch and Cree catchments (Birse and Robertson, 1976). Although rainfall is high (c. $1300 \mathrm{~mm} \mathrm{yr}^{-1}$ ), the extent to which these peats are consistently under reducing conditions is unknown. However, the existence of the sulphate effect on the igneous sites where soils are thin and rock outcrops are common (Welsh and Burns, 1987), suggests that forest-scavenging mechanisms, remain the most likely explanation for the identified sulphate trends.

Irrespective of the mechanism, it is clear that further conversion of moorland to forest has the potential to transfer additional sulphate anions to rivers. In situations where base cation dilution has made systems sensitive to anion inputs forest-exacerbated acidification may occur. This may be worse still in events directly following long drought periods. To mitigate these impacts more work is needed to determine the source of the ions: Isotope studies (Eimers et al., 2004) would help to determine the relative contribution of anthropogenic to oxidised sulphur from both forest and moorland catchments and help determine whether the effect would be expected to decrease with pollutant levels or increase with climate changes in droughts and storminess. However, for the events presented here, as $<10 \mu \mathrm{eql}^{-1}$ of additional anions reach freshwaters at $100 \%$ afforested sites in the $2005 / 2006$ surveys sulphate is unlikely to be the sole driver of the differences in $\mathrm{pH}$ identified between land uses.

\section{Nitrate}


359 Forest cover contributes to enhanced nitrate leaching as a result of atmospheric $\mathrm{NO}_{\mathrm{x}}$ 360 scavenging and following either large-scale felling or tree damage by pests or disease (Neal et 361 al, 1998; Eshleman et al., 1998). In Galloway, however, the lack of any statistically 362 significant relationship with nitrogen in any year, on any rock type, suggests that nitrate 363 leaching is unlikely to be the cause of the differences identified between land uses; any 364 influences of felling or tree damage are localised and short-term or mitigated by good forest 365 management. Forest-enhanced nitrification may however be a more significant in areas with 366 higher nitrogen deposition or greater vegetation disturbance (Eshleman et al., 2004).

\section{Marine ions}

369 Forests capture more marine ions than moorland sites; relationships are positive and highly 370 significant in all surveys. Furthermore they increase with time: chlorine coefficient $=73.87$ 371 (1996), 218.38*** (2005) and 132.55*** (2006). Forest-scavenging of sea salts is expected 372 (Fowler, 1989) and identified in other studies (Wright and Henriksen, 1980; Stoner and Gee, 373 1985; Welsh and Burns, 1987; Ormerod 1989). Furthermore a relationship between Cl:Na 374 ratio and forest cover is identified on Ordovician sites in 2005 and igneous sites in both years 375 and over $60 \mu \mathrm{eq}^{-1}$ of additional acid ions are added during the 2005 survey on both sensitive 376 geologies. Additional chloride ions passing through the system will be available to displace 377 additional $\mathrm{H}^{+}$and $\mathrm{Al}^{\mathrm{n+}}$ anions, encouraging acidity, particularly when base cations have 378 already been diluted. The sea-salt threat to freshwaters has a been widely discussed (Welsh 379 and Burns, 1987; Heath et al., 1992; Harriman et al. al, 2003; Neal and Kirchner, 2000; 380 Davies et al., 2005; Laudon, 2008) however, very few studies focus specifically on the role of 381 forest land use in exacerbating these events. Harriman et al. (2003) show that for high 382 sulphate deposition catchments with moderate sea salt impacts a $90 \%$ forested catchment has 383 the "highest chlorine gradient enhancement of acidity and labile aluminium and also the 384 highest base cation release". Larsen and Holme (2006) show that afforested spruce 385 catchments encourage larger $\mathrm{pH}$ declines and higher $\mathrm{Al}^{\mathrm{n}+}$ concentrations than natural birch 386 forests even in low sulphate deposition sites in northern Norway. The findings here support 387 the view that the forest scavenging of sea-salts may continue to pose a significant diffuse 388 pollution risk in the absence of any sulphate effects. Furthermore, as sea-salt trends fluctuate 389 with climatic forcing (Hindar et al., 2004; Wright et al., 2006; Laudon, 2008), they are 390 capable of being as strong now as in the past, and are likely to increase in significance with 391 climate change (Wright et al., 2006; Whitehead et al., 2009).

\section{Organic acids}

394 Conifer species create humus rich in organic acids with consistently lower $\mathrm{pH}$ than both 395 deciduous forest and moorland (Alexander and Cresser, 1995): Fraxinus excelsior $p H=5.5$ 
397 Sitka spruce (Picea sitchensis) $\mathrm{pH}=3.6$ (Williams, 1983). High-discharge events flushing 398 organic acids from soils to freshwaters, and have led to decreases in $\mathrm{pH}$ of more than 1.5 units, particularly where base cations are diluted (Laudon et al., 1999; Serrano et al., 2008).

400 DOC-type also varies dependant on the land use from which it originates; forest-sourced 401 DOC is often lower molecular weight and aliphatic (Ågren et al., 2008), as a result it has 402 higher potential for microbial uptake than peat-sourced carbon leading to both bacterial and photo-degradation which, in turn, also influence pH (Köhler et al., 2008).

The Ordovician forest:DOC relationship in 2005 may show evidence for a greater flushing of organic acids from Galloway forest sites during flood events. Interpretation of this trend is complicated by the controversy over the widespread increases being identified worldwide (Erlandsson et al., 2011). If DOC levels are returning to naturally high levels as a result of recovery from acid deposition (Monteith et al., 2007) the increase in DOC during forest spates may instead reflect greater recovery from acidification taking place under afforested sites in response to the reduction in forest scavenging. Further study is required to determine the exact role of DOC in Galloway, particularly as DOC can reduce negative impacts of aluminium on ecology (Serrano et al., 2008; see below).

\section{Base cation uptake}

Forest growth draws base cations, particularly calcium and magnesium, from the soil into the forest matter (Reynolds et al., 2000). The cations taken up are replaced by $\mathrm{H}^{+}$ions which increase $\mathrm{pH}$. In the absence of a strong anion to encourage cation exchange this effect is not expected to influence acidity (Nilsson et al., 1982); however, where mobile anions are input as anthropogenic pollution, organic anions or sea-salts, cation exchange can transfer hydrogen and aluminium ions to freshwaters increasing acidity. In addition forest uptake is likely to exacerbate cation dilution episodes (Erlandsson et al, 2010).

Trends in calcium and magnesium are absent in all surveys on igneous sites, and only a statistically significant increase in magnesium is identified at Ordovician sites in 2006 (Table 2); trends are, however, present at Silurian sites in 2005/6. Cation stocks on the base-poor, igneous and Ordovician soils are potentially so depleted that a forest effect is not visible, or base cation dilution may have taken place to such an extent that any trends are hidden. Either way, base-cation removal has the potential to play a part in the land use effect identified in Galloway, but is unlikely to play a large role during acid episodes beyond exacerbating the impacts of external acid inputs. 
434 In addition to chemical impacts, the drainage network under forestry can lead to increased 435 discharge to water courses (Waters and Jenkins, 1992; Kelly-Quinn et al., 1996). This 436 exacerbates base cation dilution for afforested freshwaters and decreases residence times, 437 reducing the potential for buffering. In combination with the additional acid inputs, this leads 438 to $\mathrm{H}^{+}$pulses that are longer, more severe and more abrupt at forest rather than moorland sites, 439 particularly where forests are planted on drained peaty catchments (Kelly-Quinn et al., 1996). 440 The Galloway context is similar; land use change has taken place, rainfall is high and forested 441 sites are receiving additional inputs of anions from sulphate, chloride or humic acids. In 442 Galloway, plough furrows are reported to permit rapid transit of storm runoff at the afforested 443 Loch Dee test sites planted in the 1970s (Langan and Hirst, 2004). Contemporary forest 444 management aims to reduce forest impacts on hydrology where possible (Forestry 445 Commission, 2009) and flow analysis can determine the extent to which this policy is 446 effective at reducing forest-drainage enhanced cation dilution in newer plantations.

447 Critical loadsIn the UK the critical loads model of Nilsson and Grenfeldt (1988) is used to 448 identify where sensitive management is needed to minimise the forest-enhancement of 449 acidification; this includes determining where moorland afforestation is acceptable. The 450 model identifies where sulphate loads are likely to have the greatest impacts on acid-sensitive 451 waters. In a context where sulphate scavenging is far from the only mechanism by which land 452 use change can influence acidification this approach needs to be reconsidered, particularly as 453 the model specifically excludes the influence of marine ions. The fact that $\mathrm{pH}$ and acid anions 454 show forest relationships, but no relationship is found between land use and critical load 455 exceedance (CLX) on any geology, in any year, underlines this.

456 The ecological significance of the forest acidification effect

457 Fish survival is controlled by levels of $\mathrm{pH}$ and aluminium (Levistad and Muniz, 1976; Haya 458 and Waywood, 1981; Havas and Rosseland, 1995). This is modified by the role of DOC as 459 both a source of acidity, and a moderator of the toxicity of aluminium (Laudon et al., 2005). 460 In high DOC waters $\mathrm{pH}$, rather than aluminium, controls fish survival; high brown trout 461 mortality $\left(>40 \%\right.$ ) can be expected at $\mathrm{pH} 5.0$ for sites with $10 \mathrm{mg} \mathrm{L}^{-1} \mathrm{DOC}$, but $\mathrm{pH} 4.7$ for areas 462 with $25 \mathrm{mg} \mathrm{L}^{-1} \mathrm{DOC}$ (Serrano et al., 2008). In the 2005 event Ordovician rocks have mean $\mathrm{pH}$ $463\left(\mathrm{pH}_{\mu}\right)$ of 4.8 and $\mathrm{DOC}_{\mu}$ of 12.84 whist igneous rocks have mean $\mathrm{pH}_{\mu}=3.88$ and $\mathrm{DOC}_{\mu}=8.45$. 464 The 2005 land use effect increases DOC by $8.41 \mathrm{mgL}^{-1}$ and decreases $\mathrm{pH}$ by -0.76 units on 465 Ordovician sites and by -0.81 units on igneous sites. This suggests that at Ordovician sites any 466 additional ecological tolerance to acidity brought by the forest-derived increase in DOC may 467 not be sufficient to counteract the extremes of decreasing $\mathrm{pH}$. As such, increasing forest cover 
468

469

470

471

472

473

474

475

476

477

478

479

480

481

482

483

484

485

486

487

488

489

490

491

492

493

494

495

496

497

498

499

500

501

on either Ordovician and igneous streams is likely to increase that stream's ecological vulnerability (Feeley et al., 2010).

\section{Conclusion}

There is evidence for a continued land use effect on freshwater chemistry in Galloway: statistically significant relationships show a decrease in $\mathrm{pH}$, charge balance ANC and an increase in sulphate and marine ions taking place in proportion to forest cover. There is also evidence that the significance of sulphate scavenging is declining in line with decreasing anthropogenic sulphate emissions. Conversely, sea-salt influences appear to have increased and a number of additional mechanisms have been identified that may exacerbate episodic acidification in afforested areas. As increases in the strength and frequency of both sea-salt events and rainfall-driven acid episodes are expected with climate change (Wright et al., 2006; Whitehead et al., 2009) and levels of DOC are increasing (Worral et al., 2004; Monteith et al., 2007; Laudon and Buffman, 2008), it is imperative that forest managers consider wider forest acidification effects than sulphate scavenging alone to ensure that impacts on acid-sensitive ecosystems are minimised and international policy targets are met.

\section{References}

Ågren, A., I. Buffam, K. Bishop, and Laudon, H. (2010) Modeling stream dissolved organic carbon concentrations during spring flood in the boreal forest: A simple empirical approach for regional predictions, Journal of Geophysical Research-Biogeoscience, 115, G01012.

Alexander, C.E. and Cresser, M.S., 1995, An assessment of the possible impact of expansion of native woodland cover on the chemistry of Scottish freshwaters, Forest ecology and management, 73: 1-27

BGS, 2011, British geological survey geoindex, available online at: http://www.bgs.ac.uk/geoindex/home.html (accessed 3/10/2011)

Battarbee, R.W., 1984. Diatom analysis and the acidification of lakes. Philosophical Transactions of the Royal Society London B, 305: 451-477.

Birse, E.L. and Robertson, J.S., 1976. Plant communities and soils of the lowlands and southern upland regions of Scotland. Macaulay Institute for Soil Research, Aberdeen, 87 pp. 
Bown, C. J., Shipley, B. M. and Bibby, J. S.: 1982, Soil and Land Capability for Agriculture:

503 South-West Scotland, Soil Survey of Survey of Scotland. Aberdeen: The Macaulay Institute 504 for Soil Research.

Buffam, I., Laudon, H., Temnerud, J., Mörth, CM, Bishop, K. (2007). Landscape-scale variability of acidity and dissolved organic carbon during spring flood in a boreal stream network. Journal of Geophysical Research-Biogeosciences, 112, G01022.

Davies, J., Jenkins, A., Monteith, D., Evans, C.D. and Cooper, J., 2005. How has the 511 chemistry of acid sensitive surface waters responded to the decline in acid deposition? In: D.

512 Monteith (Editor), UK Acid Water Monitoring Network:15 Year Report: Analysis and 513 interpretation of results: April 1988 - March 2003. ENSIS, London.

Dijkstra, F.A., Fitzhugh, R.D., 2003, Aluminum solubility and mobility in relation to organic carbon in surface soils affected by six tree species of the northeastern United States Geoderma $114: 33-47$

Donoghue, D.N.M. and Watt, P.J., 2006. Using LiDAR to compare forest height estimates from IKONOS and Landsat ETM+ data in Sitka spruce plantation forests. International Journal of Remote Sensing, 27(11): 2161-2175.

Donoghue, D.N.M., Watt, P.J., Cox, N.J., Dunford, R., Wilson, J., Stables, S. And Smith, S., 2004. An evaluation of the use of satellite data for monitoring early development of young Sitka spruce plantation forest growth. Forestry, 77(5): 383-396.

Dunford, R., 2008, "Forest impacts on Freshwater Acidification: an investigation of policy and practice in Galloway, South-West Scotland.” Doctoral Thesis, University of Durham, Durham, UK.

Dunford, R.W. and Donoghue, D.N.M., 2007. Forestry, remote sensing and catchment management: optical imagery for long-term tree height mapping, Annual Meeting of the Remote Sensing and Photogrammetry Society, Newcastle: 11- 14th September 2007.

Eimers, M.C., and Dillon, P.J., 2002. Climate effects on sulphate flux from forested catchments in south-central Ontario. Biogeochemistry, 61, 337-355. 
538 Eimers, M.C., \& Dillon, P.J. and Schiff, S.L., 2004, A S-isotope approach to determine the

539 relative contribution of redox processes to net SO4 export from upland, and wetland-

540 dominated catchments, Geochimica et Cosmochimica Acta, 68, 18, 3665-3674,

542 Erlandsson, M., Hjalmar Laudon, H., Fölster, J., 2010. Spatiotemporal patterns of drivers of 543 episodic acidification in Swedish streams and their relationships to hydrometeorological 544 factors, Science of the Total Environment 408 (2010) 4633-4643

545

546

Erlandsson, M., Cory,N., Fölster, J., Köhler, S., Laudon, H., Weyhenmeyer, G.A., and Bishop, K., 2011, Increasing Dissolved Organic Carbon Redefines the Extent of Surface Water Acidification and Helps Resolve a Classic Controversy, BioScience, 61,8:614-618

Eshleman, K.N., Kline, K., Morgan, R.M., Castro., N.M., Negley, T.L., 2008, Contemporary Trends in the Acid-Base Status of Two Acid-Sensitive Streams in Western Maryland, Environmental Science and Technology, 42, 56-61

Eshleman, K.N., Fiscus, D.A., Castro, N.M., Webb, J.R., Herlihy, A.T., 2004, Regionalization of disturbance-induced nitrogen leakage from mid-Appalachian forests using a linear systems model, Hydrological Processes, 18, 2713-2725

Evans, C.D. and Monteith, D., 2001. Chemical trends at lakes and streams in the UK Acid Waters Monitoring Network, 1988-2000: Evidence for recent recovery at a national scale. Hydrology and Earth Systems Science, 5(3): 351-366.

Evans, C.D. and Monteith, D., 2001. Chemical trends at lakes and streams in the UK Acid Waters Monitoring Network, 1988-2000: Evidence for recent recovery at a national scale. Hydrology and Earth Systems Science, 5(3): 351-366.

Feeley, H.B., Kerrigan, C., Fanning, P., Hannigan, E., Kelly-Quinn, M., 2010. Longitudinal extent of acidification effects of plantation forest on benthic macroinvertebrate communities in soft water streams: evidence for localised impact and temporal ecological recovery, Hydrobiologia, 671: 217-226.

Forestry Commission, 2009. Forests and water guidelines (5th Edition), Forestry Commission, Edinburgh. 
Fowler, D., Cape, J.N. and Unsworth, M.H., 1989. Deposition of atmospheric pollution on forests. Philosophical Transactions of the Royal Society London B, 324: 247- 265.

Gagkas, Z., Heal, K.V., Stuart, N. and Nisbet, T.R., 2008, Effects of broadleaf woodland cover on streamwater chemistry and risk assessments of streamwater acidification in acidsensitive catchments in the UK, Environmental Pollution 154: 232-240

Galloway Fisheries Trust, 1989. Annual Report of the Galloway Fisheries Trust, Galloway Fisheries Trust, Newton Stewart.

Harriman, R. and Morrison, B.R.S., 1981. Forestry, Fisheries and Acid Rain in Scotland. Scottish Forestry, 35(22): 89-95.

Harriman, R. and Morrison, B.R.S., 1982. Ecology of streams draining forested and nonforested catchments in an area of central Scotland subject to acid precipitation. Hydrobiologia, 88: 251-263.

\section{Harriman, R., Morrison, B.R.S., Caines, L.A., Collen, P. and Watt, A.W., 1987. Long term} changes in fish populations of acid streams and lochs in Galloway, South West Scotland. Water, Air and Soil Pollution, 32: 89-112.

Harriman, R., Watt, A.W., Christie, A.E.G., Moore, D.W., McCartney, A.G. and Taylor, E.M., 2003. Quantifying the effects of forestry practices on the recovery of upland streams from acidification. Science of the Total Environment, 310: 101-111.

Harriman, R., 1988. Patterns of surface water acidification in Scotland, Acidification in Scotland 1988. 8th November 1988, Crown Office, Regent Road, Edinburgh.

Havas, M., and B. O. Rosseland. 1995. Response of zooplankton, benthos, and fish to acidification: an overview. Water, Air, and Soil Pollution 85:51-62.

Haya, K. and Waywood, B., 1981. Acid pH and horinase activity of Atlantic Salmon (Salmo salmar) eggs. Bulletin of Environmental Toxicology, 27: 7-12

Heath, R.H., Kahl, J.S., Norton, S.A. and Fernandez, I.J., 1992. Episodic stream acidification caused by amospheric deposition of sea salts at Acadia National Park, Maine, U.S. Water Resources Research, 28: 1081-1088. 
612 Helliwell, R.C., Ferrier, R.C., Johnston, L., Goodwin, J. and Doughty, R., 2001. Land use 613 influences on acidification and recovery of freshwaters in Galloway, southwest Scotland. 614 Hydrology and Earth System Sciences, 5(3): 451-458.

616 Henriksen, A., 1980. Acidification of freshwaters - a large scale titration. In: Drabløs, D., 617 Tollan, A. (Eds.), Ecological Impact of Acid Precipitation, SNSF project, Oslo, pp. 68-74.

619 Hindar, A., Torseth, K., Henriksen, A. and Orsolini, Y., 2004. The significance of the north 620 atlantic oscillation (NAO) for sea-salt episodes and acidification-related effects in Norwegian 621 rivers. Environmental Science \& Technology, 38: 26-33.

Kelly-Quinn, M., Tierney, D., Coyle, C., and Bracken, J.J., 1996. Factors affecting the susceptibility of Irish soft-water streams to forest-mediated acidification, Fisheries Management and Ecology, 3, 287-301.

Kline, K.M., Eshleman, K.N., Morgan, R.P., and Castro, N.M., 2007, Analysis of Trends in Episodic Acidification of Streams in Western Maryland Environmental Science and Technology, 41, 5601-5607.

Köhler, S.J., Buffam, I., Laudon, H. And Bishop, K.H., 2008, Climate's control of intraannual and interannual variability of total organic carbon concentration and flux in two contrasting boreal landscape elements, Journal Of Geophysical Research, 113, G03012

Kreiser, A.M., Appleby, P.G., Natawanski, J., Rippey, B. and Battarbee, R.W., 1990. Afforestation and lake acidification : a comparison of four sites in Scotland. Philosophical Transactions of the Royal Society London B, 327: 377-383. (2008): Water quality limits for Atlantic salmon (Salmo salar L.) exposed to short term reductions in $\mathrm{pH}$ and increased aluminum simulating episodes, Hydrol. Earth Syst. Sci., 12. quality for three upland catchments at Loch Dee (Galloway SW Scotland) under contrasting land management. Hydrology and Earth System Sciences, 8(3): 422-435. 
catchment study in western Norway, Environmental Pollution 139: 440-450

Laudon, H., 2008. Recovery from episodic acidification delayed by drought and high sea salt deposition. Hydrology and Earth Systems Science, 12: 363-370.

Laudon, H., and Bishop, K.H., 1999, Quantifying sources of acid neutralisation capacity depression during spring flood episodes in Northern Sweden, Environmental pollution, 105:427-435

Laudon, H., and Buffam, I., 2008, Impact of changing DOC concentrations on the potential distribution of acid sensitive biota in a boreal stream network, Hydrology and Earth System Sciences, 12:1-11

Laudon, H., and Norton, S.A., 2010, Drivers and evolution of episodic acidification at the Bear Brook Watershed in Maine, USA, Environmental Monitoring and Assessment, 171:5969

Laudon, H., Köhler, S. and Bishop, K.H., 1999, Natural acidity or anthropogenic acidification in the spring flood of northern Sweden?, Science of the Total Environment, 234, 63-73.

Laudon, H., Poléo, A. B. S., Vollestad, L. A. and Bishop, K., 2005. Survival of brown trout during spring flood in DOC-rich streams in northern Sweden: the effect of present acid deposition and modelled preindustrial water quality. Environmental Pollution 135:121-130.

Maitland, P.S., Newson, M.D. and Best, G.A., 1990, The impacts of afforestation and forestry practice on freshwater habitats. Focus on Nature conservation No 23, Nature Conservancy Council, UK.

Mayer, R. and Ulrich, B., 1974. Conclusions on the filtering action of forests from ecosystem analysis. Oecol. Plantarum(9): 157-168.

Monteith, D. and Evans, C. (Editors), 2000. The UK Acid Waters Monitoring Network: Ten Year Report, analysisand interpretation of results 1988-1998. ENSIS Publishing, London

Muniz, I.P., Seip, H.M. and Sevaldrud, I.H., 1984. Relationship between fish populations and pH for lakes in southernmost Norway. Water, Air and Soil Pollution, 23: 97-113. 
686 Muniz, I.P. and Levistadt, H., 1980. Toxic effects of aluminium on brown trout, Salmo Trutta

687 L. In: D. Drabos and A. Tollan (D. Drabos and A. Tollan(D. Drabos and A. Tollans), 688 International Conference of Ecological Impact of Acid Precipitation. 1980. OSLO: SNSF 689 Publications, Norway, pp. 84-93.

690

691 Neal, C., Ormerod, S.J., Langan, S.J., Nisbet, T.R. and Roberts, J.D., 2004. Sustainability of 692 UK forestry: contemporary issues for the protection of freshwaters, a conclusion. Hydrology 693 and Earth System Sciences, 8(3): 589- 595

694

695 Neal, C. and Kirchner, J.W., 2000. Sodium and Chloride levels in rainfall, mist, streamwater 696 and groundwater at the Plynlimon catchments, mid-Wales: inferences on hydrological and 697 chemical controls. Hydrology and Earth System Sciences, 4: 295-310

698

699 Neal, C., Robinson, M., Reynolds, B., Neal, M., Rowland, P., Grant, S., Norris, D., Williams, 700 B., Sleep, D. and Lawlor, A., 2010, Hydrology and water quality of the headwaters of the 701 River Severn: Stream acidity recovery and interactions with plantation forestry under an 702 improving pollution climate. Science of the Total Environment, 408: 5035-5051 703

NEGTAP, 2001. Transboundary Air Pollution: Acidification, Eutrophication and Ground Level Ozone in the UK. Available online at:

708 http://www.freshwaters.org.uk/resources/documents/negtap_2001_final_report.php (Accessed: 25/02/11)

Nilsson, J. and Grennfelt, P., 1988. Critical loads for sulphur and nitrogen. 15, Report

Nilsson, S.I., Miller, H.G., and Miller, J.D. 1982 Forest Growth as a Possible Cause 714 39(1): 40-49.

716 Nisbet, T.R., Fowler, D. and Smith, R.I., 1995. An Investigation Of The Impact Of 717 Afforestation On Stream-Water Chemistry In The Loch Dee Catchment, southwest Scotland. 718 Environmental Pollution, 90(1): 111-120. 
Ormerod, S.J., Donald, A.P. and Brown, S.J., 1989. The influence of Plantation Forestry on the $\mathrm{pH}$ and Aluminium Concentration of Upland Welsh Streams, a re-examination. Environmental Pollution, 62(1): 47-62.

Ormerod, S.J. and Edwards, R.W., 1985. Stream acidity in some areas of Wales in relation to historical trends in afforestation and the usage of agricultural limestone. Journal of Environmental Management, 20: 189-197.

Ormerod S.J. \& Durance I. (2009) Restoration and recovery from acidification in upland Welsh streams over 25 years. Journal of Applied Ecology, 46, 164-174

Puhr, C.B. and Donoghue, D.N.M., 2000. Remote sensing of upland conifer plantations using Landsat TM data: a case study from Galloway, South West Scotland. International Journal of Remote Sensing, 21(4): 633-646.

Puhr, C.B., Donoghue, D.N.M., Stephen, A.B., Tervet, D.J. and Sinclair, C., 2000. Regional Patterns of Streamwater acidity and catchment afforestation in galloway, SW Scotland. Water, Air and Soil Pollution, 120: 47-70.

Rees, R.W. and Ribbens, J.C.H., 1995. Relationships between afforestation, water chemistry and fish stocks in an upland catchment in South West Scotland. Water Air and Soil Pollution, 85: 303-308.

ROTAP draft, 2010. Review of Transboundary Air Pollution: Acidification, Eutrophication, Ground Level Ozone and Heavy Metals in the UK. Available online at: http://www.rotap.ceh.ac.uk/system/files/RoTAP-complete_+document_Review_V1.pdf (Accessed: 03/02/12)

Scottish Environmental Protection Agency (SEPA), 2007. Solway Tweed River Basin Planning: A Plan of Action Consultation. Consultation Report.

Scottish Environmental Protection Agency (SEPA), 2009. The river basin management plan 752 for the Solway Tweed River Basin District. Report available online at http://www.sepa.org.uk/water/river basin_planning.aspx accessed (25/1/2011). 
Serrano, I., Biffman, I., Palm, D., Brännäs, E., and Laudon, H., 2008, Thresholds for Survival

756 of Brown Trout during the Spring Flood Acid Pulse in Streams High in Dissolved Organic Carbon, Transactions of the American Fisheries Society, 137:1363-1377.

Stalfelt, M.G., 1972. Stalfelt's Plant Ecology-Plants, the Soil and Man. Clowes \& Sons, 760 London.

Stoner, J.H., Gee, A.S. and Wade, K.R., 1984. The effects of acidification on the ecology of streams in the upper Tywi catchment in west Wales. Environmental Pollution, 35: 125-157.

Stoner, J.H. and Gee, A.S., 1985. The effects of forestry on water quality and fish in Welsh rivers and lakes. Journal of the Institute of Water Engineers and Scientists 39: 125-157.

Sutcliffe, D.W. and Carrick, T.R., 1973. Studies on mountain streams in the English lake district 1. pH, calcium and the distribution of invertebrates in the River Duddon. Freshwater Biology, 3: 437-462.

772

Waters, D., and Jenkins, A. 1992 Impacts of afforestation on water quality trends in two catchments in mid-Wales. Environmental Pollution, 77(2-3): 167-172.

Welsh, W.T. and Burns, J.C., 1987. The Loch Dee Project: runoff and surface water quality in an area subject to acid precipitation and afforestation in SW Scotland. Transactions of the Royal Society of Edinburgh: Earth Sciences, 78: 249-260.

Whitehead, P.G., Wade, A.J. and Butterfield, D., 2009, Potential impacts of climate change on water quality and ecology in six UK rivers Hydrology Research 40, 2-3 pp 113-122

Williams, B.L., 1983. Nitrogen transformations and decomposition in litter and humus beneath closed canopy Sitka spruce. Forestry, 56: 17-32.

Wright, R.F. and Henriksen, A., 1980. Regional survey of lakes and streams in southwestern Scotland, April 1979. Internal Report IR 72/80, SNSF-Project, Ås, Norway, 63 pp.

789 Wright, R.F., Aherne, J., Bishop, K., Camarero, L., Cosby, B.J., Erlandsson, M., Evans, C.D., 790 Forsius, M., Hardekopf, D.W., Helliwell, R., Hruška, J., Jenkins, A., Kopácek, J., Moldan, 791 1.F., Posch, M. and Rogora, M., 2006. Modelling the effect of climate change on recovery of 
792 acidified freshwaters: relative sensitivity of individual processes in the MAGIC model. 793 Science of the Total Environment, 365: 154-166.

794

795 Wright, R.F., 2008. The decreasing importance of acidification episodes with recovery from

796 acidification: an analysis of the 30-year record from Birkenes, Norway. Hydrology and Earth

797 Systems Science, 12: 353-362

798

799

800 
Table 1 shows water chemistry differences between surveys and geology All units are in ueql-1 except pH (units) and DOC (mg l-1). Geol = geology 802 subdivided into $\mathrm{I}=$ igneous, $\mathrm{O}=$ Ordovician and $\mathrm{S}=$ silurian; $\mu$ shows all-site mean chemistry for the survey. Alk $=$ alkalinity.

803

\begin{tabular}{|c|c|c|c|c|c|c|c|c|c|c|c|c|c|c|c|}
\hline & & Geol & $\mathrm{pH}$ & SO4 & $\mathrm{Cl}$ & $\mathrm{Na}$ & $\mathrm{Na}: \mathrm{Cl}$ & $\mathrm{Ca}$ & $\mathrm{Mg}$ & $\mathrm{K}$ & $\mathrm{ANC}_{\mathrm{CB}}$ & alk & CLX & $\begin{array}{l}\mathrm{NO}_{3-}- \\
\mathrm{N}\end{array}$ & DOC \\
\hline \multirow{13}{*}{$\begin{array}{l}3 \\
0 \\
0 \\
\frac{1}{1} \\
\frac{1}{000} \\
.0\end{array}$} & \multirow[b]{4}{*}{ ڤั } & $\mu$ & 4.65 & 42.88 & 228.17 & 250.69 & 1.12 & 136.16 & 92.92 & 10.82 & -5.63 & 0.26 & -2.40 & 10.14 & N/A \\
\hline & & I & 4.25 & 41.51 & 194.23 & 224.75 & 1.18 & 95.70 & 68.66 & 7.59 & -8.73 & 0.23 & -1.86 & 14.31 & N/A \\
\hline & & $\mathrm{O}$ & 4.66 & 40.88 & 228.84 & 252.74 & 1.11 & 124.51 & 93.02 & 10.58 & -14.01 & 0.27 & -2.23 & 7.75 & N/A \\
\hline & & $\mathrm{S}$ & 5.46 & 53.47 & 293.18 & 295.13 & 1.01 & 269.38 & 144.35 & 19.22 & 37.63 & 0.33 & -4.29 & 11.74 & N/A \\
\hline & \multirow[b]{5}{*}{ ஜ̊ } & $\mu$ & 4.66 & 24.03 & 436.43 & 339.34 & 0.79 & 95.36 & 84.29 & 10.11 & 35.09 & 0.05 & 0.23 & 13.18 & 11.66 \\
\hline & & & & & & & & & & & & - & & & \\
\hline & & 1 & 3.88 & 23.41 & 362.12 & 290.21 & 0.81 & 46.87 & 46.41 & 11.09 & 14.23 & 0.01 & 1.20 & 23.15 & 8.45 \\
\hline & & $\mathrm{O}$ & 4.80 & 23.23 & 465.92 & 358.82 & 0.78 & 92.21 & 94.47 & 9.62 & 24.12 & 0.06 & 0.12 & 9.27 & 12.84 \\
\hline & & $\mathrm{S}$ & 5.65 & 30.17 & 435.34 & 340.26 & 0.79 & 238.25 & 115.60 & 11.19 & 159.29 & 0.16 & -1.46 & 12.62 & 12.63 \\
\hline & \multirow[b]{4}{*}{ ஜ } & $\mu$ & 5.50 & 27.45 & 295.48 & 297.01 & 1.01 & 110.57 & 108.01 & 12.64 & 52.73 & 0.21 & -1.64 & 21.02 & 15.85 \\
\hline & & I & 4.78 & 27.74 & 266.79 & 272.34 & 1.03 & 65.96 & 71.85 & 13.23 & 16.66 & 0.13 & -0.34 & 31.62 & 13.50 \\
\hline & & $\mathrm{O}$ & 5.73 & 26.06 & 300.95 & 305.14 & 1.02 & 109.77 & 118.02 & 12.44 & 50.72 & 0.23 & -1.95 & 16.44 & 17.55 \\
\hline & & $\mathrm{S}$ & 5.81 & 34.16 & 328.60 & 304.44 & 0.93 & 216.73 & 133.44 & 12.66 & 147.57 & 0.25 & -2.73 & 23.20 & 11.75 \\
\hline \multirow{2}{*}{ 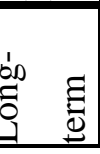 } & 1989 & $\mathrm{O}$ & 6.23 & 121.80 & 360.20 & 338.08 & 0.94 & N/A & N/A & 13.43 & N/A & N/A & N/A & 18.11 & N/A \\
\hline & 1995 & $\mathrm{O}$ & 6.10 & 118.95 & 306.13 & 289.82 & 0.94 & 132.43 & 126.71 & 11.97 & 6.05 & 0.13 & 13.51 & 11.00 & N/A \\
\hline
\end{tabular}




\begin{tabular}{|l|llllllllllllll|}
2001 & $\mathrm{O}$ & 6.01 & N/A & 281.93 & 284.56 & 0.93 & 122.40 & 126.02 & 12.22 & 10.15 & N/A & N/A & 14.12 & N/A \\
\cline { 2 - 12 } 2003 & $\mathrm{O}$ & 6.34 & N/A & 339.48 & 270.01 & 0.89 & 122.50 & 135.36 & 10.89 & 11.29 & N/A & N/A & 11.73 & 17.65 \\
\cline { 2 - 13 } 2005 & $\mathrm{O}$ & 5.87 & N/A & 373.22 & 309.68 & 0.79 & 128.06 & 125.86 & 12.02 & 8.29 & N/A & N/A & 14.11 & 13.30 \\
\hline
\end{tabular}


Table 2: Regression matrix showing the relationships between Total Forest Cover ( $\%$ of

805 catchment) and water quality variables. Columns show regression variables from regression in

806 form [Variable] $=\mathrm{k}+\mathrm{c} *$ [Forest Cover]. $\mathrm{N}$ : total number and $\mathrm{R}^{2}$ : proportion of data

807 explained by regression model. All units are in ueql-1 except $\mathrm{pH}$ (units) and DOC $\left(\mathrm{mg}^{-1}\right)$.

808 Shaded cells show negative relationships with forestry, unshaded cells show positive

809 relationships. Blank cells indicate no relationship was identified that was significant at

$810 \mathrm{P}<0.05$. CLX $=$ Critical Load Exceedance; $\mathrm{ANC}_{\mathrm{CB}}=$ charge balance acid neutralising

811 capacity.

\begin{tabular}{|c|c|c|c|c|c|c|c|c|c|c|c|c|c|}
\hline & \multicolumn{4}{|c|}{ Puhr 1996} & \multicolumn{4}{|c|}{ UoD 2005} & \multicolumn{4}{|c|}{ UoD 2006} \\
\hline & & $\mathrm{N}$ & $\mathrm{C}$ & $\mathrm{k}$ & $\mathrm{R} 2$ & $\mathrm{~N}$ & $\mathrm{c}$ & $\mathrm{k}$ & $\mathrm{R} 2$ & $\mathrm{~N}$ & $\mathrm{c}$ & $\mathrm{k}$ & $\mathrm{R} 2$ \\
\hline \multirow{13}{*}{ 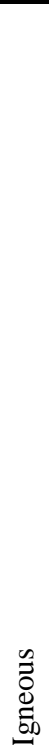 } & $\mathrm{pH}$ & 27 & $-0.36 * *$ & 4.47 & 0.36 & 28 & $-0.81 *$ & 4.26 & 0.21 & 28 & $-1.11 * *$ & 5.30 & 0.23 \\
\hline & $\mathrm{SO}_{4}$ & 27 & $20.37 * * *$ & 29.00 & 0.55 & 28 & $6.37 * *$ & 20.41 & 0.36 & 28 & $8.42 * * *$ & 23.77 & 0.49 \\
\hline & $\mathrm{Cl}$ & 27 & $97.94 * *$ & 134.06 & 0.38 & 28 & $218.38 * * *$ & 259.23 & 0.65 & 28 & $132.55 * * *$ & 204.34 & 0.46 \\
\hline & $\mathrm{Na}$ & 27 & $82.48 * *$ & 174.08 & 0.32 & 28 & $131.38 * * *$ & 228.30 & 0.61 & 28 & $105.29 * * *$ & 222.73 & 0.41 \\
\hline & $\mathrm{Na}: \mathrm{Cl}$ & 27 & $-0.19 * *$ & 1.30 & 0.27 & 28 & $-0.13 * * *$ & 0.87 & 0.56 & 28 & $-0.13 * * *$ & 1.09 & 0.44 \\
\hline & $\mathrm{Ca}$ & 27 & & & & 28 & & & & 28 & & & \\
\hline & $\mathrm{Mg}$ & 27 & & & & 28 & & & & 28 & & & \\
\hline & K & 27 & $-7.93 *$ & 12.46 & 0.24 & 28 & $-18.11 *$ & 19.62 & 0.16 & 28 & & & \\
\hline & Alkalinity & 27 & $15.15^{*}$ & -18.04 & 0.2 & 28 & & & & 28 & & & \\
\hline & $\mathrm{ANC}_{\mathrm{CB}}$ & 27 & $-0.13 * *$ & 0.31 & 0.34 & 28 & $-0.13 * * *$ & 0.05 & 0.38 & 28 & $-0.08^{*}$ & 0.17 & 0.16 \\
\hline & CLX & 27 & & & & 26 & & & & 27 & & & \\
\hline & $\mathrm{NO}_{3}-\mathrm{N}$ & 27 & & & & 28 & & & & 27 & & & \\
\hline & DOC & 0 & \multicolumn{3}{|l|}{ No Data } & 28 & & & & 28 & & & \\
\hline \multirow{13}{*}{$\begin{array}{l}\frac{.}{0} \\
.0 \\
0 \\
0 \\
0 \\
0\end{array}$} & $\mathrm{pH}$ & 51 & $-0.71 * *$ & 5.08 & 0.19 & 70 & $-0.76^{*}$ & 5.19 & 0.08 & 69 & & & \\
\hline & $\mathrm{SO}_{4}$ & 51 & $15.62 * * *$ & 31.77 & 0.49 & 70 & $5.01 * *$ & 20.67 & 0.1 & 69 & $9.07 * * *$ & 21.41 & 0.17 \\
\hline & $\mathrm{Cl}$ & 51 & $73.87 * * *$ & 185.79 & 0.29 & 70 & $170.81 *$ & 378.85 & 0.09 & 69 & $118.47 * *$ & 240.17 & 0.14 \\
\hline & $\mathrm{Na}$ & 51 & $67.19 * *$ & 213.59 & 0.2 & 70 & $109.29 *$ & 303.11 & 0.07 & 69 & $124.93 * *$ & 241.05 & 0.15 \\
\hline & $\mathrm{Na}: \mathrm{Cl}$ & 51 & & & & 70 & $-0.06 * *$ & 0.81 & 0.12 & 69 & & & \\
\hline & $\mathrm{Ca}$ & 51 & & & & 70 & & & & 69 & & & \\
\hline & $\mathrm{Mg}$ & 51 & & & & 70 & & & & 69 & $36.71^{*}$ & 99.19 & 0.09 \\
\hline & $\mathrm{K}$ & 51 & $-7.96 * *$ & 15.22 & 0.2 & 70 & $-9.05 * *$ & 14.23 & 0.13 & 69 & $-8.64 * *$ & 16.87 & 0.1 \\
\hline & Alkalinity & 51 & & & & 70 & $-24.03 *$ & 36.37 & 0.08 & 69 & & & \\
\hline & $\mathrm{ANC}_{\mathrm{CB}}$ & 51 & $-0.12 * * *$ & 0.34 & 0.22 & 70 & $-0.05 *$ & 0.08 & 0.08 & 69 & & & \\
\hline & CLX & 50 & & & & 70 & & & & 68 & & & \\
\hline & $\mathrm{NO}_{3}-\mathrm{N}$ & 50 & & & & 70 & & & & 68 & & & \\
\hline & DOC & 0 & \multicolumn{3}{|l|}{ No Data } & 70 & $8.41 * * *$ & 8.56 & 0.17 & 69 & & & \\
\hline \multirow{5}{*}{$\underset{\stackrel{\Xi}{\Xi}}{\stackrel{\Xi}{\Xi}}$} & $\mathrm{pH}$ & 12 & $-1.83 *$ & 6.36 & 0.35 & 11 & & & & 12 & & & \\
\hline & $\mathrm{SO}_{4}$ & 12 & & & & 11 & & & & 12 & & & \\
\hline & $\mathrm{Cl}$ & 12 & & & & 11 & & & & 12 & & & \\
\hline & $\mathrm{Na}$ & 12 & & & & 11 & & & & 12 & & & \\
\hline & $\mathrm{Na}: \mathrm{Cl}$ & 12 & & & & 11 & & & & 12 & & & \\
\hline
\end{tabular}




\begin{tabular}{|l|l|l|l|l|l|l|l|l|l|l|l|l|}
$\mathrm{Ca}$ & 12 & & & & 11 & $-604.68^{*}$ & 516.89 & 0.39 & 12 & $-334.01^{*}$ & 376.37 & 0.35 \\
\hline $\mathrm{Mg}$ & 12 & & & & 11 & $-221.78^{*}$ & 217.80 & 0.44 & 12 & & & \\
\hline $\mathrm{K}$ & 12 & $-18.83^{*}$ & 28.51 & 0.41 & 11 & & & & 12 & & & \\
\hline Alkalinity & 12 & $-247.03^{*}$ & 159.50 & 0.33 & 11 & $-773.73^{*}$ & 515.84 & 0.4 & 12 & $-402.16^{*}$ & 339.78 & 0.33 \\
\hline $\mathrm{ANC}_{\mathrm{CB}}$ & 12 & & & & 11 & $-0.44^{*}$ & 0.37 & 0.38 & 12 & & & \\
\hline $\mathrm{CLX}$ & 12 & & & & 11 & & & & 12 & & & \\
\hline $\mathrm{NO}_{3}-\mathrm{N}$ & 12 & & & & 11 & & & & 12 & & & \\
\hline $\mathrm{DOC}$ & 0 & \multicolumn{2}{|l}{ No Data } & & 11 & & & & 12 & & & \\
\hline
\end{tabular}


813 Table 3 Relationships between forestry and water quality variable identified by multiple

814 regression. Chlorine is used to represent marine ions, relationships with sodium are very similar.

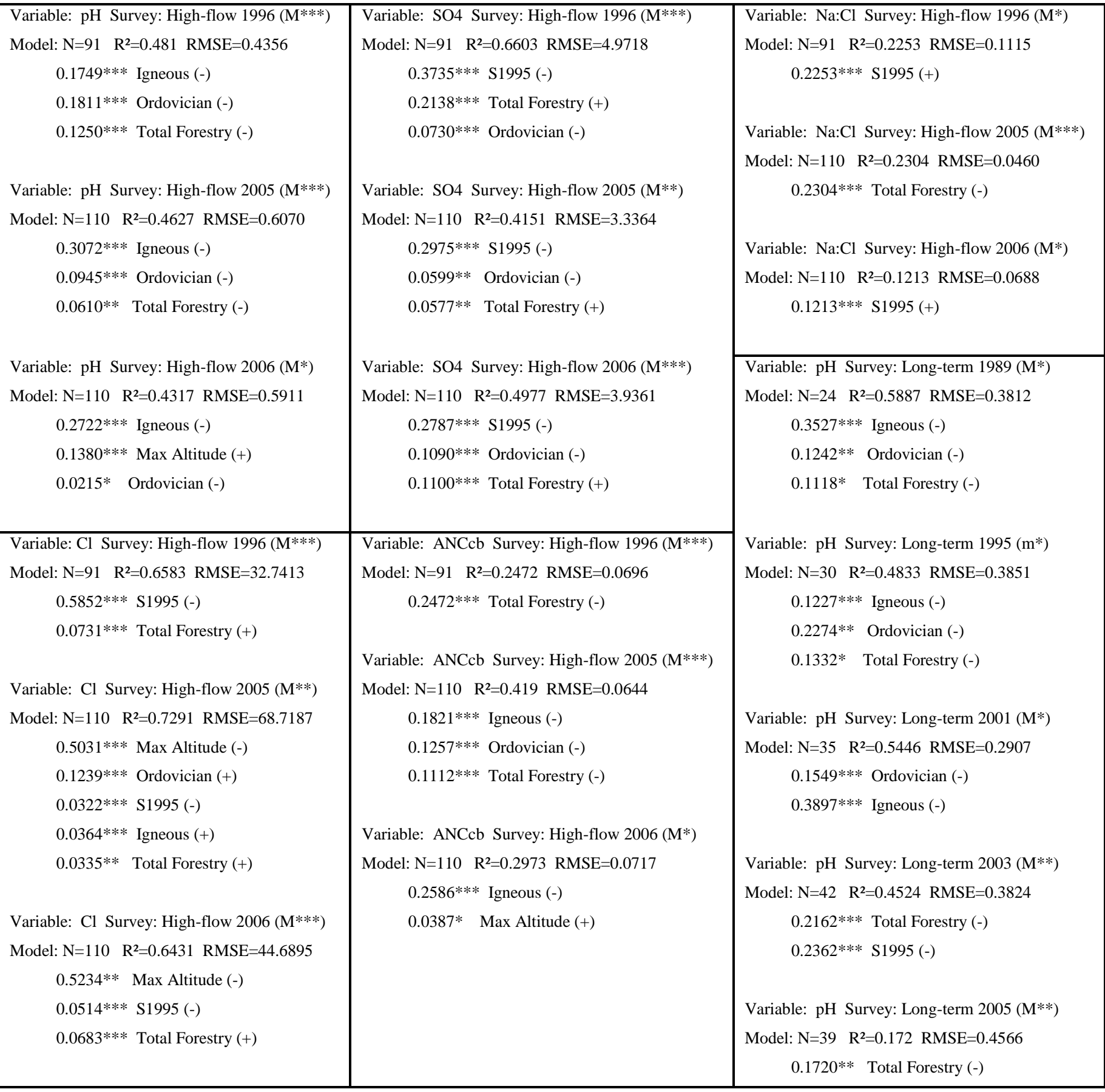

$815 \mathrm{M}=$ model by addition; $\mathrm{m}=$ model by removal; Significance: $* * *=\mathrm{P}<0.001 * * \mathrm{P}<0.01$

$816 * \mathrm{P}<0.5 ;(-)$ negative relationship (+) positive relationship. 
Figure 1 The rivers of Galloway Forest District. Reaches were characterised by SEPA using invertebrate data in terms of their likelihood of meeting good ecological status. Those highlighted in red are at risk of failing the directive's requirement of good ecological status as a result of forest enhanced acidification (SEPA classes 1a/1b). The catchments highlighted in the table below have over $50 \%$ of their river length affected by forest enhanced acidification.

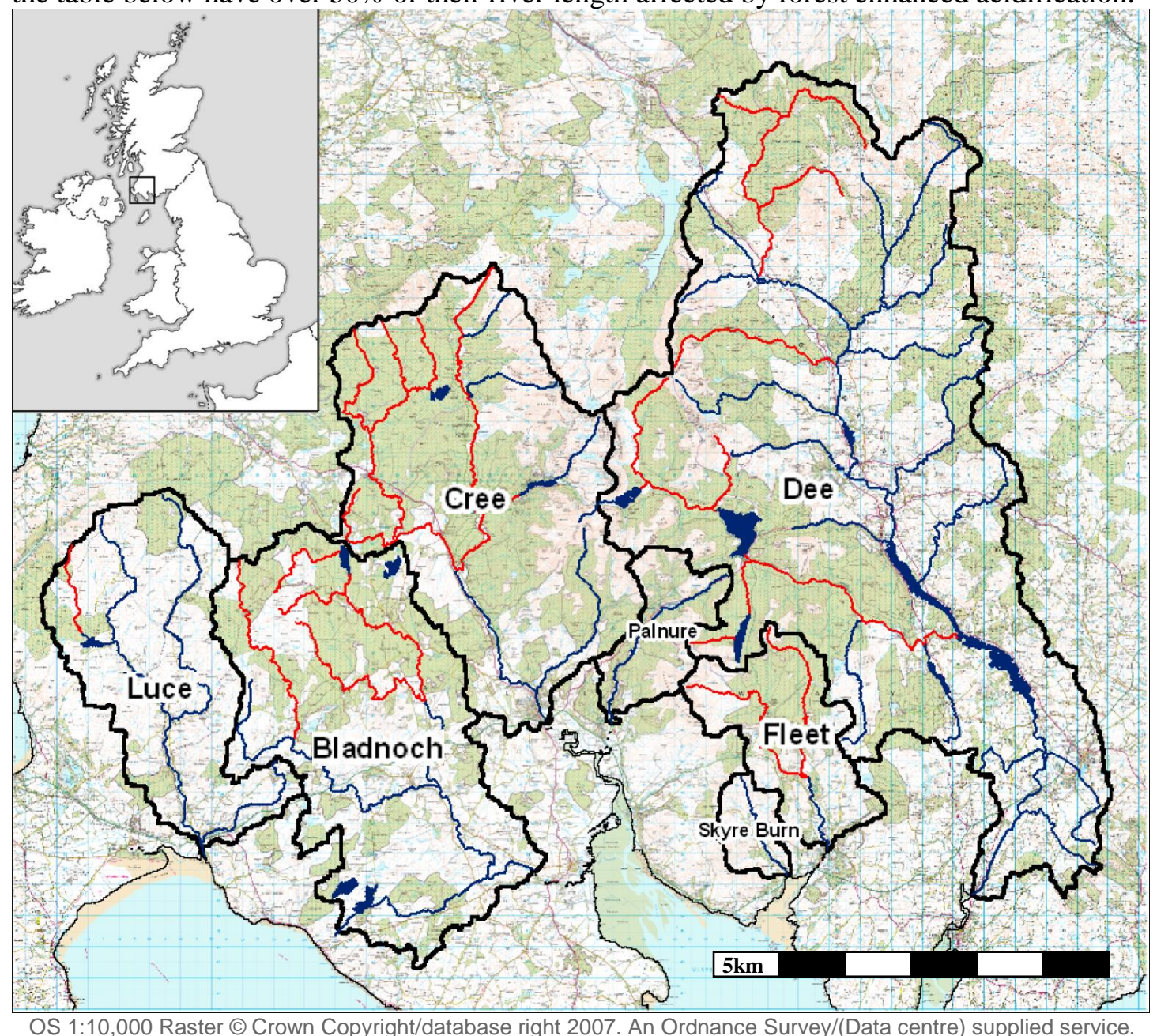


825 Figure 2 Galloway's acid sensitivity in a UK context. A and B show Non-sea salt $\mathrm{SO}_{4}{ }^{2-}$ concentration

826 in rainfall $\left(\mu \mathrm{eql}^{-1}\right) 1986$ and 1997, modified from NEGTAP (2001). C shows local Geology from 827 British Geological Survey 1:625,000 (BGS, 2011). D-F shows total sulphur deposition (keq ha ${ }^{-1}$ year $^{-1}$ 828 S) 1970, 1980 and 1995, source: Centre for Ecology and Hydrology.

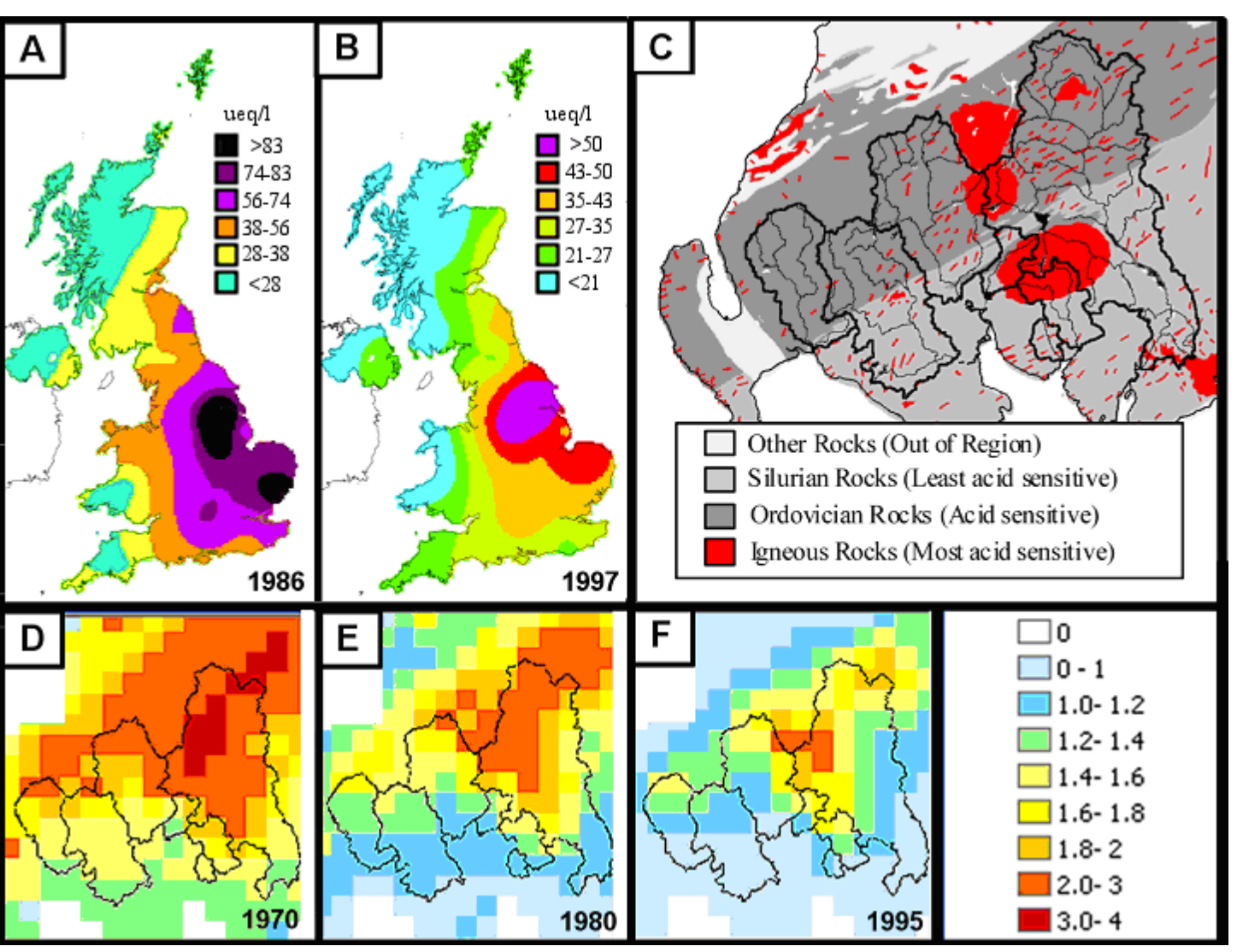

830

831

832 
834

835

836

837

838

839

840

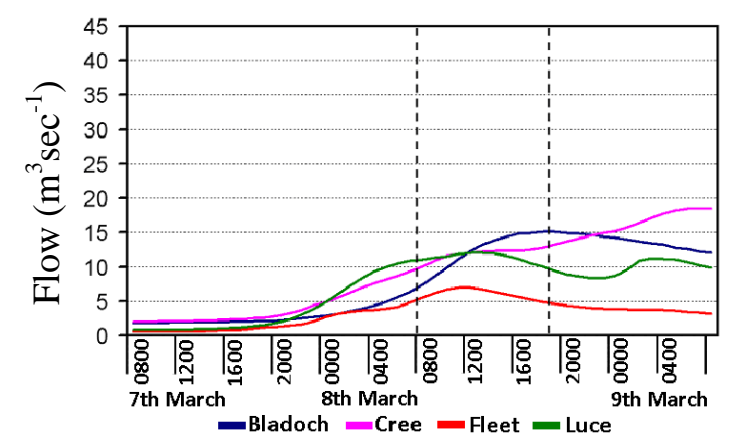

B: 2005
Figure 3 Water quality data: A-C hydrographs comparing storm events for the rivers Fleet, Cree, Bladnoch and Luce and sampling times (within the vertical lines).

A: 1996

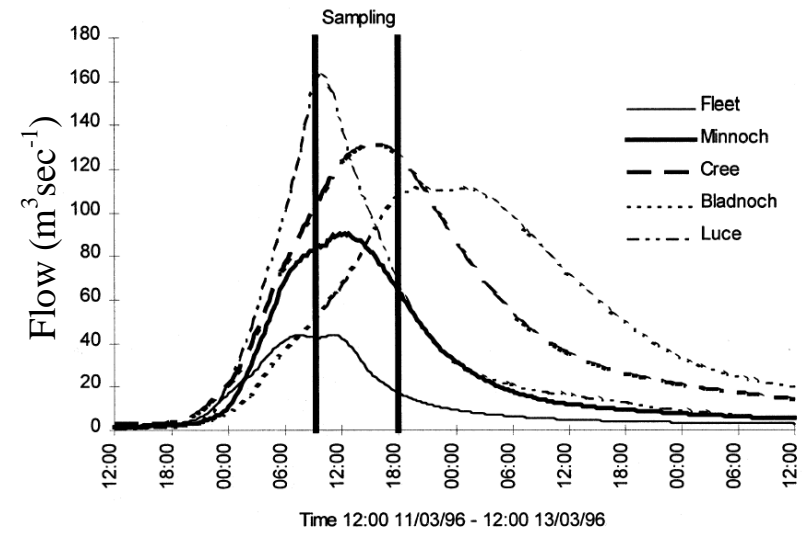

C:2006

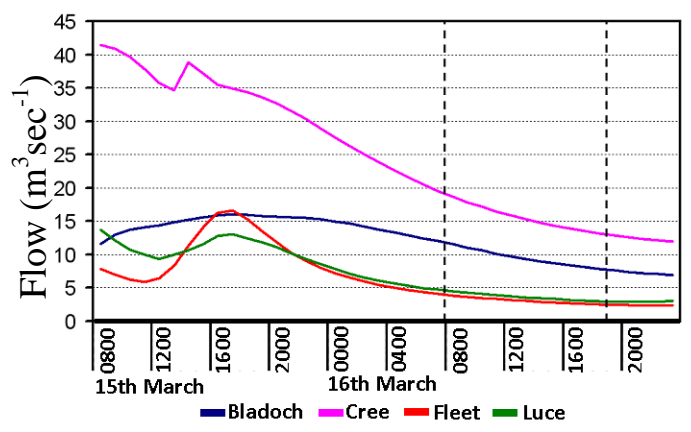


842 Figure 4: Relationship between annual median $\mathrm{pH}$ and total forest cover (TF) for the long-term SEPA

843 datasets 1989 -2005 showing data and fitted regression lines of the form $[\mathrm{pH}]=\mathrm{k}+\mathrm{c} *$ [Forest Cover].

$844 \mathrm{~N}$ : total number and $\mathrm{R}^{2}$ : proportion of data explained by regression model. Statistical Significance $*=$

$845 \mathrm{P}<0.05 * *=\mathrm{P}<0.01 * * *=\mathrm{P}<0.001$.

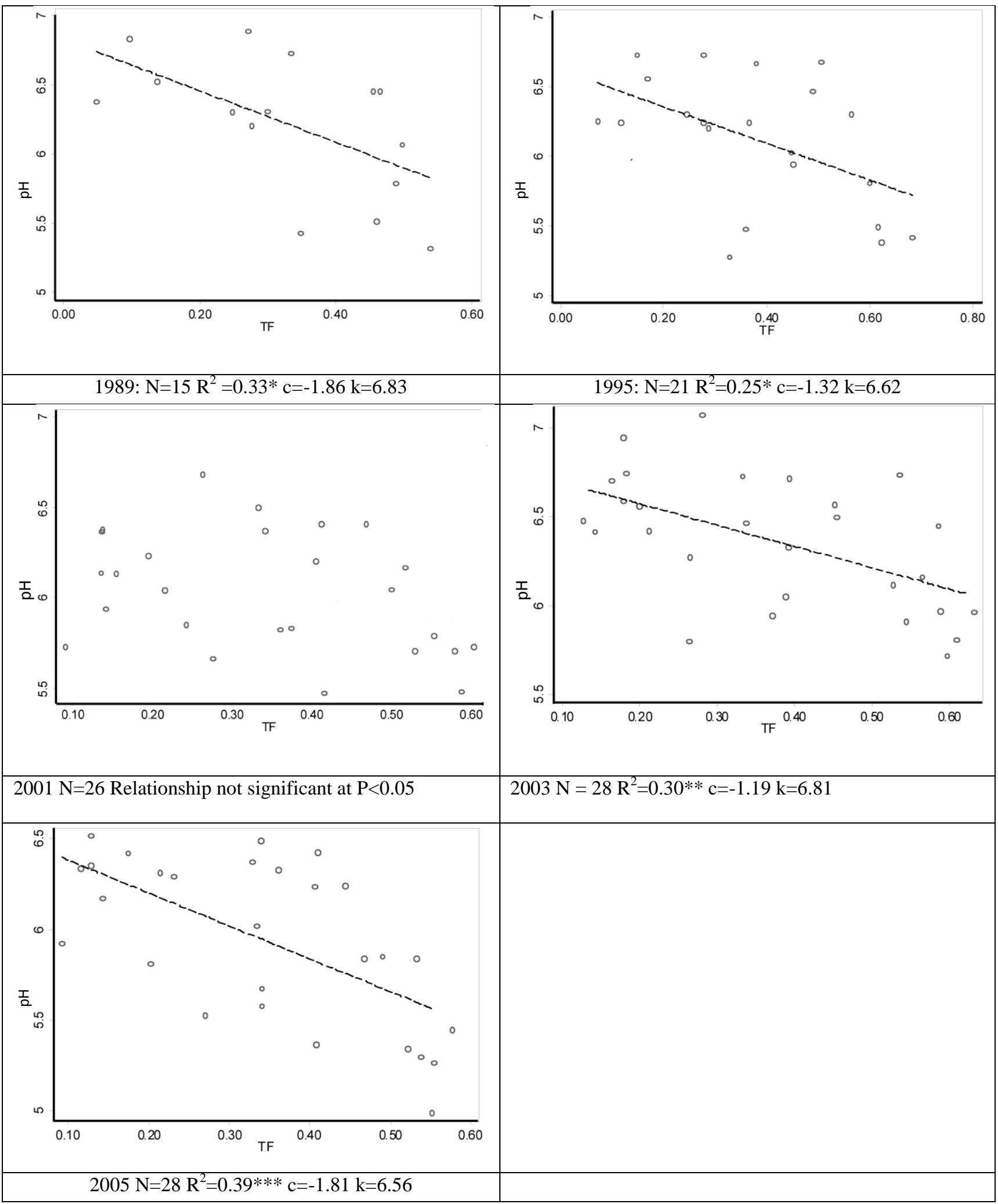

846 
848 Figure 5 PCA loading plot for multiple regression variables showing first and second components.

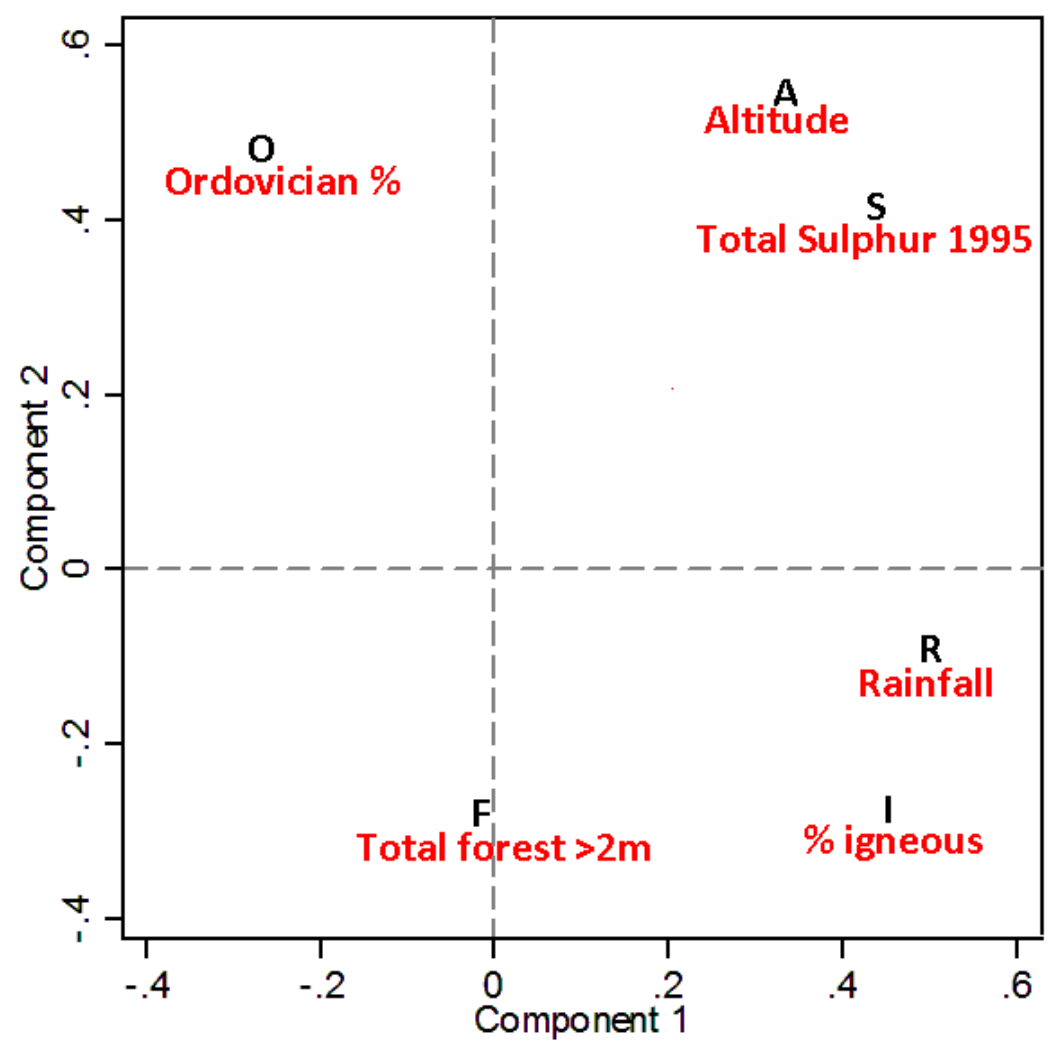

850 